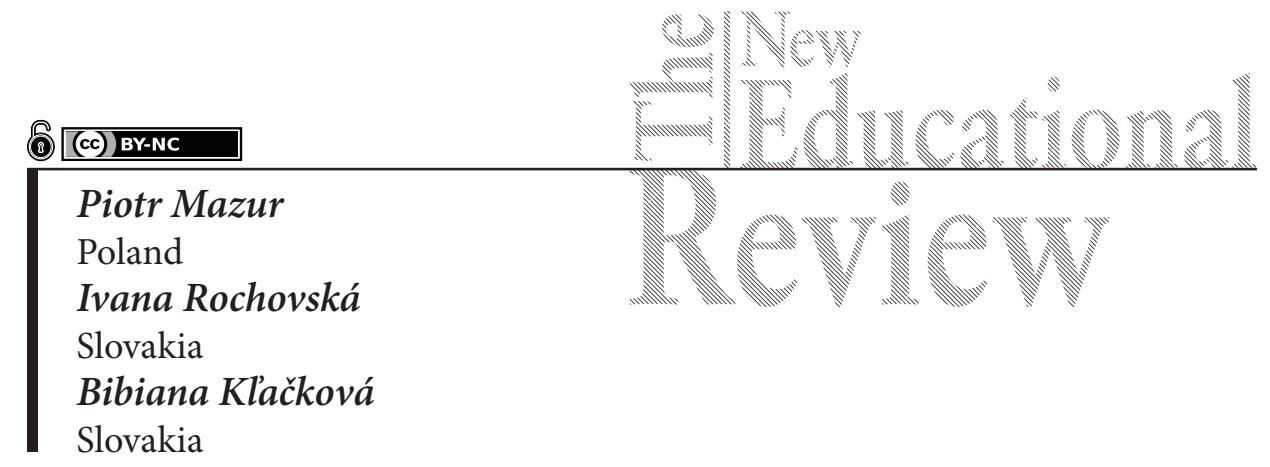

\title{
The Issue of Homeschooling in Poland, the Czech Republic and Slovakia from the Perspective of Parents of Homeschooled Children
}

DOI: $10.15804 /$ tner.2019.58.4.04

\begin{abstract}
This research addresses the opinions of parents of homeschooled children on the issue of homeschooling. Through both quantitative and qualitative research - a questionnaire with 78 parents of homeschooled children from Poland, the Czech Republic and Slovakia, their opinions on the selection of a school for their children, problems in compulsory examination, and the selection of teaching methods and forms were found out. On the basis of the research findings, it was possible to state that criteria for school selection was not related to problems in the compulsory examination of the children, and the pedagogical education of the respondents (parents) did not influence the selection of didactic methods or forms.
\end{abstract}

Key words: homeschooling, individual (home) education, methods and forms of homeschooling, parents of homeschooled children, unschooling.

\section{Introduction}

Poland, the Czech Republic and Slovakia are European countries with a similar tradition of the education system, where education is considered to be an institutionalized process. However, in these countries an increasing number of parents 
wish to homeschool their children. Homeschooling has gradually become rooted in the legislation of European countries and education is no longer acquired or takes place only at school, but also outside of the school, on the grounds that the concept of compulsory school attendance is replaced by the concept of compulsory education. In all European countries, except Germany, individual education in the home (or other conditions) is legal, at least for children of a certain age group.

According to Rochovská, Mazur \& Dolinská (2019), in Poland, since 1991 it has been legally possible to implement homeschooling in a public or a non-public nursery school (ISCED 0), a primary school (ISCED 1,2), a grammar school, or a secondary school (ISCED 3). In the Czech Republic, homeschooling has become an equivalent form of fulfilling the compulsory school attendance requirement at the first stage of primary school (ISCED 1) since 2005, later also at the second stage of primary school (ISCED 2) since 2016 and it should be permitted at all elementary schools. In Slovakia, homeschooling has been enacted from 2008 and yet it is allowed only at the first stage of primary school level (ISCED 1).

For comparison, in Russia, the legal possibility for homeschooling to exist was already established in 1992. In Estonia, the 1992 Educational Act allowed compulsory schooling to be carried out at home and in Hungary, the 1993 Educational Act introduced the status of a "private student" who can be educated individually, out of school (Kostelecká, 2010).

Homeschooling in Poland, the Czech Republic and Slovakia still appears to be an option for a minority, up to date it concerns about $0.3 \%$ of all pupils in each country, however, the trend is rising. To compare, Ray (2019) estimated that about 2.3 million students were home-educated in the United States, and that the homeschool population had been continuing to grow at an estimated $2 \%$ to $8 \%$ per annum over the previous few years.

Researchers in the United States of America found out that "homeschooled students score as well as or better than their public school peers on college entrance examinations" (Murphy, 2014, p. 21; Cogan, 2010; Ray \& Weller, 2003).

The most commonly used term in relation to the research issue is homeschooling. In Slovakia and the Czech Republic, there is the concept of individual education rooted in legislation, while homeschooling is one of its forms. In Polish legislative documents, the term home education is used (Rochovská, Mazur \& Dolinská, 2019). In other countries, Lithuanian law speaks about self-education or independent studies, while Russian law about family education (Kostelecká, 2010).

Unschooling is often considered to be a branch of homeschooling. While other homeschoolers may do "school at home" and follow a set curriculum, unschoolers learn primarily through everyday life experiences - experiences that they choose 
and that therefore automatically match their abilities, interests, and learning styles (Wheatley, 2009).

In research conducted by psychologists Gray \& Riley (2013) on a sample of 232 families who practiced unschooling, they found out that as many as $83 \%$ of children continued their studies at universities and had no difficulty getting involved in classical education.

According to Gray \& Riley (2015) the great majority of adults who had been unschooled, are very happy with their unschooling. Nearly all of them valued the freedom it gave them to pursue their own interests in their own ways, and many of them reported that unschooling promoted their capacities for self-motivation, self-direction, personal responsibility and continued learning.

In practice, the Polish, Czech and Slovak homeschooling was quite varied, ranging from unschooling to the strict pursuit of the official school curriculum in the home environment (Kašparová, 2015). Methods and ways of teaching were less important to them than the thoughts themselves. Once they found some interesting ideas they wanted to test, they used an unlimited number of methods for how to implement them (Rochovská, Mazur \& Dolinská, 2019).

\section{Problem of the Research}

Stemming from the research results by Rochovská \& Mazur (2019) the conditions for the provision of individual (home) education in Slovakia, the Czech Republic and Poland are similar. It differs mainly in the age category of learners, the requirements for a guarantor with qualification for (primary) teaching, and the recommendation from pedagogical and psychological counseling (compulsory in Poland). According to Rochovská, Mazur \& Dolinská (2019), and also Kostelecká (2012, 2015), an education following the philosophy of unschooling is not legally rooted in any of these countries. However, many parents are already experimenting with unschooling of their children and they would welcome the possibility of this form of education being legalized.

If an unschooled child succeeds in the final examination at the end of the school year, there is no problem for parents, or for school where he/she is enrolled. Therefore, the parents often take care of the selection of a school for their child and prefer a school that is "homeschool friendly", and has rich experience in home education.

The question to gather the opinions of parents of homeschooled children in Poland, the Czech Republic and Slovakia, on the process of homeschooling, became the topic of this research.

The aim of the research was to find out, if the selection of school (where a child is enrolled) is influenced by problems in compulsory examination, and if the 
pedagogical education of parents influences the selection of teaching methods and forms of homeschooling.

Three hypotheses have been formulated as a result of field experience and previous empirical findings (Rochovská \& Mazur, 2019; Rochovská, Mazur \& Dolinská, 2019):

H1: Respondents who select a school for their children based on the experience of schools with individual education, and the form of compulsory examination, mention fewer problems in compulsory examination than respondents who select a school for their children according to other criteria.

$\mathrm{H} 2$ : Respondents with no pedagogical education prefer unschooling more than respondents with pedagogical education.

H3: Respondents with pedagogical education prefer classical methods and forms (working with textbooks, workbooks, reading and writing) more than respondents with no pedagogical education.

\section{Methodology of Research}

\section{General Background of Research}

This research was carried out between January 2019 and September 2019. It was a part of the larger project entitled "Individual Education in the V4 Countries - A Comparative Research Study". In this larger research project, quantitative and qualitative research methods (an unstructured interview, a method of examining documents, a questionnaire) were used to find out the conditions for homeschooling in the V4 countries.

\section{Sample of Research}

78 parents of homeschooled children were involved in the research: 30 from Poland (PL), 27 from the Czech Republic (CZ), and 21 from Slovakia (SK). The respondents were briefed on the aim of the research, they voluntarily participated in the research, and they were promised to remain anonymous.

The research sample consisted of $10.26 \%$ men and $89.74 \%$ women. In accordance with Stevens (2001) it can be stated that mothers primarily assume responsibility for the work of homeschooling in families, or in the larger homeschooling supporting structure. 
The data related to the number of respondents' children in home education are presented in Table 1, and the data related to the age of the home educated children are presented in Table 2.

Table 1. Number of respondents' children in home education

\begin{tabular}{|c|c|c|c|c|c|c|c|c|}
\hline \multirow{2}{*}{$\begin{array}{l}\text { Number of } \\
\text { children }\end{array}$} & \multicolumn{2}{|c|}{ PL } & \multicolumn{2}{|c|}{$\mathrm{CZ}$} & \multicolumn{2}{|c|}{ SK } & \multicolumn{2}{|c|}{ Total } \\
\hline & $n$ & $\%$ & $n$ & $\%$ & $n$ & $\%$ & $n$ & $\%$ \\
\hline 1 & 23 & 76.67 & 16 & 59.26 & 13 & 61.90 & 52 & 66.67 \\
\hline 2 & 4 & 13.33 & 7 & 25.93 & 7 & 33.33 & 18 & 23.08 \\
\hline 3 & 1 & 3.33 & 4 & 14.81 & 0 & 0.00 & 5 & 6.41 \\
\hline 4 & 1 & 3.33 & 0 & 0.00 & 0 & 0.00 & 1 & 1.28 \\
\hline No answer & 1 & 3.33 & 0 & 0.00 & 1 & 4.76 & 2 & 2.56 \\
\hline Total & 30 & 100 & 27 & 100 & 21 & 100.00 & 78 & 100 \\
\hline
\end{tabular}

Table 2. The age of the home educated children

\begin{tabular}{lcccccccccccc}
\hline $\begin{array}{c}\text { Age of } \\
\text { children } \\
\text { (years) }\end{array}$ & $\mathbf{5}$ & $\mathbf{6}$ & $\mathbf{7}$ & $\mathbf{8}$ & $\mathbf{9}$ & $\mathbf{1 0}$ & $\mathbf{1 1}$ & $\mathbf{1 2}$ & $\mathbf{1 3}$ & $\mathbf{1 4}$ & $\mathbf{1 8}$ & $\mathbf{1 9}$ \\
\hline $\mathrm{PL}$ & 0 & 2 & 8 & 2 & 3 & 6 & 4 & 5 & 2 & 1 & 2 & 1 \\
\hline $\mathrm{CZ}$ & 2 & 4 & 9 & 3 & 8 & 6 & 4 & 3 & 1 & 2 & 0 & 0 \\
\hline SK & 0 & 5 & 8 & 6 & 4 & 3 & 0 & 1 & 1 & 0 & 0 & 0 \\
\hline Total & 2 & 11 & 25 & 11 & 15 & 15 & 8 & 9 & 4 & 3 & 2 & 1 \\
\hline
\end{tabular}

Note: In Poland, compulsory school attendance starts from 6 years of age, while children aged 7 years are enrolled in Primary School after Pre-primary School education. In the Czech Republic, compulsory school attendance starts from 5 years of age, while in Slovakia from 6 years of age. In Table 2, the age of homeschooled children in Slovakia is from 6 to 13 years. Because in Slovakia homeschooling is allowed only for children in Primary School - ISCED 1, two respondents, with children aged 12 and 13, reported enrollment of their children in a school in the Czech Republic, where home education is also approved for this age category.

More than half of the respondents from each country answered they had no pedagogical education. $34.67 \%$ of them answered they had pedagogical education (Table 3). The majority of them had less than 5 years' teaching practice (Table 4 ). Some of them, living in Poland, answered they have taught Theology, Preschool Teaching, Primary Teaching, Educational Therapy, Arts, History, Religious Education, Psychology, Speech Therapy, and Music. Others from the Czech Republic answered they have taught Czech language, Special Education, Primary Teaching, 
Secondary Teaching, Philosophy, and Theology. Respondents from Slovakia answered they have taught Social Pedagogy, Special Pedagogy, foreign languages, Philosophy, Preschool Teaching, Primary Teaching, and Montessori Teaching.

Table 3. Pedagogical education of the respondents (\%)

\begin{tabular}{lcccccccc}
\hline $\begin{array}{c}\text { Pedagogical } \\
\text { education }\end{array}$ & \multicolumn{2}{c}{$\mathrm{PL}$} & \multicolumn{2}{c}{$\mathrm{CZ}$} & \multicolumn{2}{c}{ SK } & \multicolumn{2}{c}{ Total } \\
\hline & $\boldsymbol{n}$ & $\%$ & $\boldsymbol{n}$ & $\%$ & $\boldsymbol{n}$ & $\%$ & $\boldsymbol{n}$ & $\%$ \\
\hline Yes & 9 & 30.00 & 7 & 25.93 & 10 & 47.62 & 26 & 33.33 \\
\hline No & 19 & 63.33 & 19 & 70.37 & 10 & 47.62 & 48 & 61.54 \\
\hline Unfinished & 1 & 3.33 & 1 & 3.70 & 0 & 0.00 & 2 & 2.56 \\
\hline Other response & 1 & 3.33 & 0 & 0.00 & 1 & 4.76 & 2 & 2.56 \\
\hline
\end{tabular}

Note: In Poland, the pedagogical education of parents is not a requirement for permission for the home education of their children. In the Czech Republic parents of homeschooled children must meet the condition of having completed at least secondary education (it does not have to be pedagogical) with a maturity exam (ISCED 3) (in the case of a learner at the first stage of Primary School, ISCED 1), or higher education (ISCED 5) (in the case of a learner at the second stage, ISCED 2). In Slovakia, individual education is allowed to be conducted only by a person (a parent or a guarantor), who meets the qualification requirements of higher education of the second stage (ISCED 5), established for teachers on the first stage of Primary School.

Table 4. The length of the teaching practice of the respondents (\%)

\begin{tabular}{lccccccc}
\hline $\begin{array}{c}\text { Work } \\
\text { experience } \\
\text { (years) }\end{array}$ & $\begin{array}{c}\text { No work } \\
\text { experience }\end{array}$ & up to 5 & 6-10 & 11-15 & 16-20 & 21-25 & 26-30 \\
\hline \% resp. & 66.67 & 16.67 & 5.13 & 6.41 & 1.28 & 2.56 & 1.28 \\
\hline PL & 70.00 & 16.67 & 3.33 & 3.33 & 0.00 & 3.33 & 3.33 \\
\hline CZ & 74.07 & 18.52 & 3.70 & 3.70 & 0.00 & 0.00 & 0.00 \\
\hline SK & 52.38 & 14.29 & 9.52 & 14.29 & 4.76 & 4.76 & 0.00 \\
\hline
\end{tabular}

\section{Instrument and Procedures}

During the research, an online structured questionnaire was used, which contained 10 open-ended questions, 7 of which were relevant to this research. The responses concerned the number of children in home (individual) education, their age, the selection of school for their child, methods and forms of education of their child, the compulsory examination of their child, potential difficulties in the examination, and other opinions related to the issue of homeschooling. 
The questions were designed by the researchers for the purposes of this research, so expert opinion and pilot testing were necessary. Five respondents with extensive experience of home (individual) education commented on each question in order to assess its constructive and content validity. Each question was assessed on a scale of 5 (relevant) - 0 (irrelevant). The result was expressed as a percentage (94.8\%).

In the main study the respondents answered the questions electronically (online, through social groups related to home education) ${ }^{1}$.

\section{Data Analysis}

The data analysis was both quantitative and qualitative (descriptive). Respondents' responses obtained through the questionnaire were categorized and described. The hypotheses were statistically tested. To evaluate the data, Pearson's chi-square test of independence was used.

\section{Research Results and Discussion}

H1: Respondents who select a school for their children based on the experience of the school with individual education, and on the form of the compulsory examination, mention fewer problems in compulsory examination than respondents who select a school for their children according to other criteria.

Independent variable: criterion of the selection of school (experiences of the school with individual (home) education and form of compulsory examination; other criteria).

Dependent variable: problems mentioned when examining children.

According to respondents' responses (Table 5), the choice of school depended mainly on the school's experience with home education (36.45\%), and the form of the compulsory examination (16.82\%). As Rochovská, Mazur \& Dolinská (2019) stated, in all the countries mentioned, homeschooled children are examined by the school where they are enrolled to check whether the prescribed curricula is being

1 Social groups Edukacja Domowa (Home Education), Edukacja domowa w praktyce (Home Education in Practice), Domáce a komunitné vzdelávanie alebo homeschooling \& unschooling (Home and Community Education or Homeschooling \& Unschooling), Domácí a komunitní vzdělávání(Home and Community Education). 
fulfilled. This is the state requirement. While in Slovakia and the Czech Republic this took place twice a year, in Poland it was only once a year.

Among other criteria (9.35\%), the respondents mentioned for example, respect for the child's opinion, the possibility of teaching through Skype, practicing Waldorf pedagogy, etc.

Table 5. School selection criteria (Rochovská, Mazur \& Dolinská, 2019)

\begin{tabular}{|c|c|c|c|c|c|c|c|c|}
\hline \multirow[t]{2}{*}{ Respondents' responses } & \multicolumn{2}{|c|}{ PL } & \multicolumn{2}{|c|}{$\mathrm{CZ}$} & \multicolumn{2}{|c|}{ SK } & \multicolumn{2}{|c|}{ Total } \\
\hline & $n$ & $\%$ & $n$ & $\%$ & $n$ & $\%$ & $n$ & $\%$ \\
\hline School's experience with home education & 20 & 42.55 & 10 & 27.78 & 9 & 37.50 & 39 & 36.45 \\
\hline Form of compulsory examination & 7 & 14.89 & 4 & 11.11 & 7 & 29.17 & 18 & 16.82 \\
\hline Director and school approach & 5 & 10.64 & 3 & 8.33 & 1 & 4.17 & 9 & 8.41 \\
\hline $\begin{array}{l}\text { Recommendation of family and ac- } \\
\text { quaintances }\end{array}$ & 3 & 6.38 & 6 & 16.67 & 0 & 0.00 & 9 & 8.41 \\
\hline Place of residence & 1 & 2.13 & 5 & 13.89 & 0 & 0.00 & 6 & 5.61 \\
\hline Flexibility of testing dates & 3 & 6.38 & 2 & 5.56 & 1 & 4.17 & 6 & 5.61 \\
\hline Access to children & 2 & 4.26 & 0 & 0.00 & 2 & 8.33 & 4 & 3.74 \\
\hline $\begin{array}{l}\text { Recommendation of parents of other } \\
\text { children in home education }\end{array}$ & 0 & 0.00 & 3 & 8.33 & 0 & 0.00 & 3 & 2.80 \\
\hline $\begin{array}{l}\text { Other recommendations (e.g. Home Ed- } \\
\text { ucation Associations, Home Education } \\
\text { Coordinators) }\end{array}$ & 3 & 6.38 & 0 & 0.00 & 0 & 0.00 & 3 & 2.80 \\
\hline Others & 3 & 6.38 & 3 & 8.33 & 4 & 16.67 & 10 & 9.35 \\
\hline
\end{tabular}

The literal wording of some of the respondents' statements:

"I selected a school for my child according to the method of examination and the opportunity to learn what the child wants and not the school". (a respondent from the Czech Republic)

"We wanted it to be a specialized school friendly to home education, with a wide range of extra hours in the morning, for mixed age groups, with excellent teachers and friendly exams that truly assess students' knowledge, with the possibilities to be examined near home, with effective secretarial services by phone and email". (a respondent from Poland) 
"We wanted to cooperate with the school if possible (participation in events, clubs ...), but we were not accepted anywhere in the area, so we chose a school well-established for homeschooled children, even though it was far away". (a respondent from Slovakia)

"We chose the school in Brrezová (the Czech Republic) because it provides all the necessary information to study and on the examination on the school Internet Moodle. We have an overview of what is going on at school at the time and what to focus on". (a respondent from Slovakia)

According to the research findings by Rochovská, Mazur \& Dolinská (2019), parents of homeschooled children mostly said that the compulsory examination was done to their satisfaction, without problems and in a pleasant atmosphere (41.96\%). Most respondents from Poland replied that a written examination, and then an oral interview with the child, were used in their country. Only some of the respondents from the Czech Republic and Slovakia answered that the examination consisted of presenting the child's portfolio (7.14\%). Among other problems with the examination (3.57\%), a stressful environment, an examination led by the teacher, individual agreement with the teacher, etc. were mentioned. One child from Poland was enrolled abroad, in a UK school, and there was no compulsory examination.

The literal wording of some of the respondents' statements:

"The examination was just a formality. My child's level of knowledge is two years higher than in a regular school". (a respondent from Poland)

"We were sent the main school subject tests to do at home. After the tests we discussed with the teachers at school. The children in the discussion reviewed what they had learned, and what they needed to work on. The main part of the examination was the presentation of the portfolio". (a respondent from Slovakia)

Most respondents replied they did not encounter difficulties when their children were examined. Therefore, this was as predicted in hypothesis $\mathrm{H} 1$ where difficulties with the examination were expected to be related to the selection criteria for enrollment in the school. These respondents probably chose the school based on the school's experience with individual (home) education, and according to the form of the compulsory examination (Table 5).

Respondents encountering difficulties with the examination (Table 6) reported mainly misunderstanding of homeschooling by some teachers $(22.58 \%)$. This was 
probably a group of respondents who educated children with the application of the philosophy of unschooling (Table 8).

Relating to the examination, respondents also mentioned bad timing, long waiting, and lack of time (19.35\%). Among other problems mentioned (38.71\%), there were, for example, parent's fear, exhausting and nearly inhuman examinations, teachers' unprofessionalism, the child not wanting to attend exams, test errors, tests incompatible with the curriculum, teacher-driven exams, no interest in the child's portfolio, challenging travel, etc.

The literal wording of some of the respondents' statements:

"The nonsensical adherence of the teacher to the literal text of the answers given by the textbooks, and no possibility to choose your own textbooks". (a respondent from the Czech Republic)

"It was difficult to be examined in a mainstream school because they demanded the full accuracy of the curriculum. In a free school it worked without any problems". (a respondent from the Czech Republic)

"After writing the test we received only grades without comments. We were waiting a long time for the result but we were not given any comments. (a respondent from Poland)

"I wasn't satisfied. We agreed on something else with the teacher and the reality was different". (a respondent from Slovakia)

Table 6. Problems in compulsory examination of the child (Rochovská, Mazur \& Dolinská, 2019)

\begin{tabular}{lcccccccc}
\hline \multirow{2}{*}{ Respondents' responses } & \multicolumn{2}{c}{ PL } & \multicolumn{2}{c}{ CZ } & \multicolumn{2}{c}{ SK } & \multicolumn{2}{c}{ Total } \\
\cline { 2 - 10 } & $\boldsymbol{n}$ & $\%$ & $\boldsymbol{n}$ & $\%$ & $\boldsymbol{n}$ & $\%$ & $\boldsymbol{n}$ & $\%$ \\
\hline $\begin{array}{l}\text { Misunderstanding of home- } \\
\text { schooling by some teachers }\end{array}$ & 1 & 7.14 & 2 & 22.22 & 4 & 50.00 & 7 & 22.58 \\
\hline $\begin{array}{l}\text { Bad timing / long waiting / } \\
\text { lack of time }\end{array}$ & 4 & 28.57 & 2 & 22.22 & 0 & 0.00 & 6 & 19.35 \\
\hline Nervousness of the child & 1 & 7.14 & 1 & 11.11 & 2 & 25.00 & 4 & 12.90 \\
\hline $\begin{array}{l}\text { Dissatisfaction with the } \\
\text { examiner }\end{array}$ & 2 & 14.29 & 0 & 0.00 & 0 & 0.00 & 2 & 6.45 \\
\hline Others & 6 & 42.86 & 4 & 44.44 & 2 & 25.00 & 12 & 38.71 \\
\hline
\end{tabular}


In this research the learning outcomes of pupils were not studied. The reason was, according to Lines (1995), there was no evidence whether the same children would perform better or worse in a public classroom or in the homeschooling arrangement. Even when homeschooled children tested well, it was not possible to establish that the homeschooling intervention was responsible for the results (Reich, 2005). Besides this researchers rejected "the notion of the primacy of achievement scores in understanding the impact of homeschooling" (Murphy, 2014, p. 11).

The data about the school selection criteria and problems in compulsory child examination given by the respondents are presented in the contingency table (Table 7).

Table 7. School selection criteria and problems in compulsory child examination from the respondents' point of view

\begin{tabular}{|c|c|c|c|c|c|}
\hline \multicolumn{4}{|c|}{ Actual frequency } & \multicolumn{2}{|c|}{ Expected frequency } \\
\hline & $\begin{array}{l}\text { Problems } \\
\text { when exam- } \\
\text { ining children } \\
(31)\end{array}$ & $\begin{array}{l}\text { Without } \\
\text { problems } \\
\text { when exam- } \\
\text { ining children } \\
(47)\end{array}$ & & $\begin{array}{l}\text { Problems } \\
\text { when exam- } \\
\text { ining children }\end{array}$ & $\begin{array}{l}\text { Without } \\
\text { problems } \\
\text { when exam- } \\
\text { ining children }\end{array}$ \\
\hline $\begin{array}{l}\text { Criteria: } \\
\text { experiences } \\
\text { of school with } \\
\text { individu- } \\
\text { al (home) } \\
\text { education, } \\
\text { and form of } \\
\text { compulsory } \\
\text { examination } \\
\text { (57) }\end{array}$ & 24 & 33 & $\begin{array}{l}\text { Criteria: } \\
\text { experiences } \\
\text { of school with } \\
\text { individu- } \\
\text { al (home) } \\
\text { education, } \\
\text { and form of } \\
\text { compulsory } \\
\text { examination }\end{array}$ & 22.65 & 34.35 \\
\hline $\begin{array}{l}\text { Other crite- } \\
\operatorname{ria}^{\star}(21)\end{array}$ & 7 & 14 & $\begin{array}{l}\text { Other crite- } \\
\text { ria }^{*}\end{array}$ & 8.35 & 12.65 \\
\hline
\end{tabular}

* except experiences of school with individual (home) education, and form of compulsory examination

Among respondents who selected a school for their children based on the experience of school with individual education, and the form of the compulsory examination, 24 (42.11\%) mentioned problems in the children's examination, and $57.89 \%$ mentioned no problems in the children's examination. Among the respondents who chose a school for their children based on other criteria, 
$7(33.33 \%)$ mentioned problems in the children's examination, and $14(66.67 \%)$ mentioned no problems in the children's examination.

To evaluate the data, Pearson's chi-square test of independence was used. There was not a statistically significant difference $\left(\chi^{2}(1)=0.493, p=0.483\right)$ between the respondents in the number of problems in the compulsory examination.

Respondents who selected a school for their children based on the school's experience with individual (home) education, and on the form of the compulsory examination, did not mention fewer problems when the children were examined than the respondents who selected a school for their children according to other criteria. Hypothesis $H 1$ was rejected.

H2: $\quad$ Respondents with no pedagogical education prefer unschooling more than respondents with pedagogical education.

Independent variable: pedagogical education of a parent (yes, no). Dependent variable: preferred methods and forms of teaching (unschooling; other methods and forms).

The methods and forms of education mentioned by the respondents were grouped into categories, with no didactic method and form structure applied, but retained as reported by respondents (Table 8). According to the respondents, most of them answered that they practiced unschooling (14.12\%), mainly in the Czech Republic and Slovakia.

The literal wording of some of the respondents' statements:

"We are dedicated to topics that children open themselves or topics that somehow arise from the same life situations (family experiences, experience outside, normal functioning, opening a new book ...)." (a respondent from Slovakia)

"The child learns itself." (a respondent from Slovakia)

"Natural and intuitive or none." (a respondent from Slovakia)

"None, I mean natural education. The child learns itself. My husband and I only suggest the topics. We follow the child instead of teach the child." (a respondent from Poland)

More respondents from Poland mentioned mainly working with a textbook $(12.68 \%)$, reading and speaking (11.27\%). Among other methods and forms (13.53\%), the respondents mentioned, for example, workshops, demonstrations, teaching with a private teacher, etc. 
The literal wording of some of the respondents' statements:

"We learn at home according to textbooks and school requirements, rather in a classic way. We watch movies on the subject, talk a lot, and learn outside. We write less in the workbook and practice more on the internet." (a respondent from the Czech Republic) "Lapbooks, excursions, classic workbooks, playing the piano..." (a respondent from Slovakia)

"Various. Projects, lapbooks, textbooks, Pinterest work cards, aids inspired by Montessori pedagogy, games and educational toys..." (a respondent from Poland)

Table 8. Methods and forms selection (Rochovská, Mazur \& Dolinská, 2019)

\begin{tabular}{lcccccccc}
\hline \multirow{2}{*}{ Respondents' responses } & \multicolumn{2}{c}{ PL } & \multicolumn{2}{c}{ CZ } & \multicolumn{2}{c}{ SK } & \multicolumn{2}{c}{ Total } \\
\cline { 2 - 10 } & $\boldsymbol{n}$ & $\%$ & $\boldsymbol{n}$ & $\%$ & $\boldsymbol{n}$ & $\%$ & $\boldsymbol{n}$ & $\%$ \\
\hline Unschooling & 7 & 9.86 & 9 & 18.75 & 8 & 15.69 & 24 & 14.12 \\
\hline Working with a textbook & 9 & 12.68 & 4 & 8.33 & 2 & 3.92 & 15 & 8.82 \\
\hline Reading and speaking & 8 & 11.27 & 1 & 2.08 & 5 & 9.80 & 14 & 8.24 \\
\hline Projects & 6 & 8.45 & 2 & 4.17 & 4 & 7.84 & 12 & 7.06 \\
\hline Working with a workbook & 3 & 4.23 & 3 & 6.25 & 3 & 5.88 & 9 & 5.29 \\
\hline Montessori & 2 & 2.82 & 2 & 4.17 & 5 & 9.80 & 9 & 5.29 \\
\hline Excursions & 6 & 8.45 & 1 & 2.08 & 2 & 3.92 & 9 & 5.29 \\
\hline Plays & 4 & 5.63 & 2 & 4.17 & 2 & 3.92 & 8 & 4.71 \\
\hline Online form (e.g. Khan & 3 & 4.23 & 3 & 6.25 & 2 & 3.92 & 8 & 4.71 \\
Academy) & & & & & & & & \\
\hline Experiential learning & 3 & 4.23 & 1 & 2.08 & 4 & 7.84 & 8 & 4.71 \\
\hline Learning outside & 3 & 4.23 & 1 & 2.08 & 2 & 3.92 & 6 & 3.53 \\
\hline Experiments, discovering & 2 & 2.82 & 2 & 4.17 & 2 & 3.92 & 6 & 3.53 \\
\hline Internet & 3 & 4.23 & 0 & 0.00 & 1 & 1.96 & 4 & 2.35 \\
\hline Interest activities & 2 & 2.82 & 1 & 2.08 & 1 & 1.96 & 4 & 2.35 \\
\hline Watching movies, videos & 2 & 2.82 & 2 & 4.17 & 0 & 0.00 & 4 & 2.35 \\
\hline Community schools, & 1 & 1.41 & 0 & 0.00 & 2 & 3.92 & 3 & 1.76 \\
groups & & & & & & & & \\
\hline Portfolio creation & 0 & 0.00 & 2 & 4.17 & 0 & 0.00 & 2 & 1.18 \\
\hline Lapbooks & 1 & 1.41 & 1 & 2.08 & 0 & 0.00 & 2 & 1.18 \\
\hline Others & 8.45 & 11 & 22.92 & 6 & 11.76 & 23 & 13.53 \\
\hline & & & & & &
\end{tabular}


The data about pedagogical practice of the respondents and selection of methods and forms given by the respondents are presented in the contingency table (Table 9).

Table 9. Pedagogical practice of the respondents and selection of methods and forms from the point of view of respondents

\begin{tabular}{|c|c|c|c|c|c|}
\hline \multicolumn{4}{|c|}{ Actual frequency } & \multicolumn{2}{|c|}{ Expected frequency } \\
\hline & $\begin{array}{l}\text { Practicing } \\
\text { unschooling } \\
(24)\end{array}$ & $\begin{array}{l}\text { Practic- } \\
\text { ing other } \\
\text { methods and } \\
\text { forms }{ }^{*}(54)\end{array}$ & & $\begin{array}{l}\text { Practicing } \\
\text { unschooling }\end{array}$ & $\begin{array}{l}\text { Practicing } \\
\text { other meth- } \\
\text { ods }^{*}\end{array}$ \\
\hline $\begin{array}{l}\text { Pedagogical } \\
\text { education } \\
(26)\end{array}$ & 9 & 17 & $\begin{array}{l}\text { Pedagogical } \\
\text { education }\end{array}$ & 8 & 18 \\
\hline $\begin{array}{l}\text { With no } \\
\text { pedagogical } \\
\text { education } \\
\text { (52) }\end{array}$ & 15 & 37 & $\begin{array}{l}\text { With no } \\
\text { pedagogical } \\
\text { education }\end{array}$ & 16 & 36 \\
\hline
\end{tabular}

* except unschooling

Among the respondents with pedagogical education, 9 (34.62\%) mentioned practicing unschooling, and 17 (65.38\%) mentioned other methods and forms of education. From the respondents with no pedagogical education, 15 (28.85\%) mentioned practicing unschooling, and 37 (71.15\%) mentioned other methods and forms of education.

To evaluate the data, Pearson's chi-square test of independence was used. There was not a statistically significant difference $\left(\chi^{2}(1)=0.271, p=0.603\right)$ between the respondents in the preference for unschooling compared to other methods and forms of education. Respondents with no pedagogical education did not prefer unschooling more than respondents with pedagogical education. Hypothesis $\mathrm{H} 2$ was rejected.

H3: Respondents with pedagogical education prefer classical methods and forms (working with textbooks, workbooks, reading and writing) more than respondents with no pedagogical education.

Independent variable: pedagogical education of a parent (yes, no). 
Dependent variable: preferred methods and forms of teaching (working with textbooks, workbooks, reading and writing; other methods and forms).

The data about pedagogical practice of the respondents and selection of methods and forms given by the respondents are presented in the contingency table (Table 9).

Table 10. Pedagogical practice of the respondents and selection of methods and forms from the respondents' point of view

\begin{tabular}{|c|c|c|c|c|c|}
\hline \multicolumn{4}{|c|}{ Actual frequency } & \multicolumn{2}{|c|}{ Expected frequency } \\
\hline & $\begin{array}{l}\text { Working with } \\
\text { textbooks, } \\
\text { workbooks, } \\
\text { reading and } \\
\text { speaking }(38)\end{array}$ & $\begin{array}{l}\text { Practic- } \\
\text { ing others } \\
\text { methods and } \\
\text { forms* }(40)\end{array}$ & & $\begin{array}{l}\text { Working with } \\
\text { textbooks, } \\
\text { workbooks, } \\
\text { reading and } \\
\text { speaking }\end{array}$ & $\begin{array}{l}\text { Practic- } \\
\text { ing others } \\
\text { methods and } \\
\text { forms* }\end{array}$ \\
\hline $\begin{array}{l}\text { Pedagogical } \\
\text { education } \\
(26) \\
\end{array}$ & 12 & 14 & $\begin{array}{l}\text { Pedagogical } \\
\text { education }\end{array}$ & 12.67 & 13.33 \\
\hline $\begin{array}{l}\text { With no } \\
\text { pedagogical } \\
\text { education } \\
(52)\end{array}$ & 26 & 26 & $\begin{array}{l}\text { With no } \\
\text { pedagogical } \\
\text { education }\end{array}$ & 25.33 & 26.67 \\
\hline
\end{tabular}

* except working with workbooks, reading and speaking

Among the respondents with pedagogical education, 12 (46.15\%) mentioned practicing classical methods and forms of education (working with textbooks, workbooks, reading and speaking), and 14 (53.85\%) mentioned other methods and forms of education. From the respondents with no pedagogical education, 26 (50\%) mentioned practicing classical methods and forms of education (working with textbooks, workbooks, reading and speaking), and 26 (50\%) mentioned other methods and forms of education.

To evaluate the data, Pearson's chi-square test of independence was used. There was not a statistically significant difference $\left(\chi^{2}(1)=0.103, p=0.749\right)$ between the respondents in the preference of classical methods and forms of education compared to other methods and forms of education. Respondents with pedagogical education did not prefer classical methods and forms (working with textbooks, workbooks, reading and writing) more than respondents with no pedagogical education. Hypothesis $H 3$ was rejected. 
Respondents also had the opportunity to comment on the issue of individual (home) education. 56.66\% of the respondents from Poland used this option. They mentioned this form of education as more effective and very suitable for children who had a hobby (e.g., dedicated to music), as improving family relationships, with the remark that children were happier. They recommended this form of learning to everyone. Some respondents also reported that they encountered misunderstanding among teachers who did not know and did not understand alternative forms of education. The respondents also complained about their child's learning style and interests being limiting by the compulsory curriculum.

The respondents from the Czech Republic (25.93\%) reported that individual (home) education had a pleasant course, and it was an enrichment for the whole family. One respondent stated that for their child compulsory examination was very stressful, therefore, they were forced to transfer their child from one school to another school. Another respondent noted that if they had an alternative school with free access to education in the neighborhood, they would rather enroll their child there.

Respondents from Slovakia (28.57\%) stated that home education was a very good decision for them because their children had very positive results and, in addition, it enriched their family relationships. As negatives, they put the administrative burden in dealing with the application for individual (home) education, and the restriction of the compulsory curriculum. They would also like to be able to educate children in this form in the second stage of primary school in Slovakia.

Respondents from each country similarly mentioned that homeschooling enriched their family relationships. This compared with research results by Murphy (2014, p. 10), "building healthy families was one of the four driving motives for homeschooling". Homeschooling prevented the generational gap between children and parents; built healthy relationships among siblings; and established a nurturing family environment (Murphy, 2014; Farris \& Woodruff, 2000; Mayberry, 1993; Webb, 1989).

According to Hulová, Rochovská, \& Klein (2018), in Slovakia, the Czech Republic and Poland, the trend in education was for an inclusive education, supporting heterogeneity and development of the child's personality without comparison with other children, which is in accordance with the idea of homeschooling.

Many parents were experimenting with unschooling (Table 8). According to research results by Kašparová (2012), there were families in the Czech Republic who were already practicing the unschooling life strategy and did not separate the world of children from the world of adults, educating their children at home. The situation in Slovakia and Poland is similar (Rochovská, Mazur \& Dolinská, 2019). 
In these countries, unschooling as a teaching strategy is not rooted in the legislation. However, if learners educated in this way succeeded in the half-year and end-of-year examinations at the school they were enrolled in, it was not a problem for any party involved. These parents and pedagogues admitted that it was not possible to formulate any set of "best practices" for learning. Rather, they learnt with their children, and they also considered it as positive if they did not know how to explain something to the children immediately.

\section{Conclusions}

The findings of this research have important implications for the parents of homeschooled children as well as for professionals dealing with the issue of homeschooling. It has been found that the criteria for school selection was not related to problems in the compulsory examination of the children. It has also been found that the pedagogical education of the respondents (parents) did not influence the selection of didactic methods and forms.

However, a limitation of the research is the awareness that the research sample is non-representative. This is due to the fact that researchers usually have limited opportunities to require homeschooling families to participate in the research.

According to the research results, the parents were experimenting with unschooling. However, they understood the term unschooling in highly variable ways. The results of the research encourage us to continue to study this issue and to extend the research also to qualitative investigation of the practice of unschooling in families with homeschooled children in Poland, the Czech Republic and Slovakia, and the problems they encountered in the compulsory examination.

\section{Acknowledgements}

This research is published as part of the GAPF Project No. 6/90/2018 "Individual education in the V4 countries - A comparative research study", and the VEGA Project no. 1/0383/19 "Analysis of the state in technical education and development of technical skills of pupils at primary school".

\section{References}

Cogan, M.F. (2010). Exploring academic outcomes of homeschooled students. Journal of College Admission, 208, 18-25. 
Farris, M., \& Woodruff, S. (2000). The future of home schooling. Peabody Journal of Education, 75(1/2), 233-255.

Gray, P. \& Riley, G. (2013). The challenges and benefits of unschooling, according to 232 families who have chosen that route. Journal of Unschooling and Alternative Learning, 7(14), 1-27.

Gray, P. \& Riley, G. (2015). Grown Unschoolers' Evaluations of Their Unschooling Experiences: Report I on a Survey of 75 Unschooled Adults. Other Education: The Journal of Educational Alternatives, 4(2), 8-32.

Hulová, Z., Rochovská, I., \& Klein, V. (2018). The issue of age homogeneity in groups from the kindergarten teacher's perspective. The New Educational Review, 53(3), 203-215.

Kašparová, I. (2012). Children, work and education: first steps to unschooling as a result of current institutional child-care crisis in the Czech Republic. In Proceedings of Belgrade International Conference on Education (pp. 31-42). Belgrade, Serbia: Tomorrow People Organization.

Kašparová, I. (2015). Homeschooling: Freedom and control in Czech education. Global Dialogue, 5(3), 31-32.

Kostelecká, Y. (2010). Home education in the post-communist countries: Case study of the Czech Republic. International Electronic Journal of Elementary Education, 3(1), 29-44.

Lines, P.M. (1995). Home Schooling (ERIC Digest, Number 95). Eugene, OR: ERIC Clearinghouse on Educational Management, University of Oregon.

Mayberry, M. (1993). Effective learning environments in action: The case of home schools. The School Community Journal, 3(1), 61-68.

Murphy, J. (2014). The Social and Educational Outcomes of Homeschooling. Sociological Spectrum, 34(3), 1-33.

Ray, B.D. (2019). Research facts on homeschooling. Homeschool fast facts. In National Home Education Research Institute, January 7, 2019. Retrieved 15/07/2019 from https:// www.nheri.org/research-facts-on-homeschooling/

Ray, B. \& Weller, N. (2003). Homeschooling: An overview and financial implications for public schools. School Business Affairs, 69(5), 22-26.

Reich, R. (2005). Why homeschooling should be regulated. In B.S. Cooper (Ed.), Home schooling in full view (pp. 109-120). Greenwich, CT: Information Age Publishing.

Rochovská, I. \& Mazur, P. 2019. Theoretical Basis of Individual (Home) Education in Slovakia, the Czech Republic and Poland. Pedagogika.sk. Slovak Journal for Educational Sciences, 10(4), 254-273.

Rochovská, I., Mazur, P., \& Dolinská, E. (2019). Homeschooling in Poland, the Czech Republic and Slovakia. Education Policy, Management and Quality, 11(2).

Stevens, M. (2001). Kingdom of children: Culture and controversy in the homeschooling movement. Princeton, NJ: Princeton University Press.

Webb, J. (1989). The outcomes of home-based education: Employment and other issues. Educational Review, 41(2), 121-133.

Wheatley, K. (2009). Unschooling: An oasis for development and democracy. Encounter, 22, 27-32. 